\title{
Профілактика ускладнень перкутанної вертебропластики
}

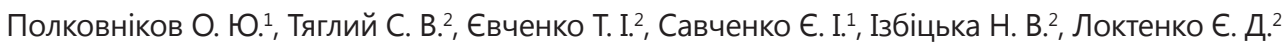 \\ 1 Запорізький державний медичний університет, Запоріжжя, Україна \\ ${ }^{2}$ КУ "Запорізька обласна клінічна лікарня" ЗОР, Запоріжжя, Україна
}

Перкутанна вертебропластика - один із широко застосовуваних у практиці малоінвазивних методів хірургічного лікування; найнебезпечнішим ускладненням вертебропластики є вихід акрилового цементу в хребтовий канал.

Мета дослідження: оптимізація техніки перкутанної вертебропластики для профілактики можливих ускладнень.

Матеріали та методи. Проведено аналіз результатів лікування 112 пацієнтів, що перебували на лікуванні у відділенні нейрохірургії КУ “ЗОКЛ” ЗОР з 2017 по 2019 рр. Усім пацієнтам було проведено пункційну вертебропластику. У 10 випадках при позиціонуванні пункційної голки не проводилася контрастна спондиловенографія. В інших спостереженнях після позиціонування пункційної голки в тілі хребця проводилася контрастна спондиловенографія, при наявності виходу контрасту за межі тіла хребця проводилася репозиція голки або при неможливості уникнути виходу контрасту вертебропластика не проводилася - 2 спостереження; при ознаках “швидкого” венозного дренажу вертебропластика виконувалася з експозицією в часі.
Результати дослідження та їх обговорення. Серед усіх пацієнтів було 80 жінок і 32 чоловіки. Серед жінок було 16 молодого віку (25-44 роки), 26 середнього віку (45-60 років) і 38 літнього віку (61-75 років). Серед чоловіків було 20 молодого віку, 4 середнього віку і 6 літніх. За типом патології випадки розподілилися наступним чином: "агресивні” гемангіоми - 94, патологічний злам тіла хребця на тлі остеопорозу - 8, мієломна хвороба -2 , травматичний злам тіла хребця -4 випадки і в 4-х спостереженнях - метастатичне ураження. За локалізацією: грудний відділ хребта - 40, попереково-крижовий відділ хребта - 66 та множинне ураження (г.в.п. + п.к.в.п.) у 6-ти випадках. В 1 спостереженні відзначався гіпотензивний синдром.

Серед 10 випадків, у яких не застосовувалася контрастна контрольна спондиловенографія, в 1 відзначено міграцію цементу в хребтовий канал.

Висновки: У профілактиці ускладнень пункційної вертебропластики велику роль відіграє відбір пацієнтів, а також контрастна спондиловенографія, яка дозволяє прогнозувати міграцію акрилового цементу в хребтовий канал. 